\title{
The Segmentation of Neutron Digital Radiography Image through the Edge Detection Method
}

\author{
Ayu Fitri Amalia ${ }^{1, a, *}$ and Widodo Budhi ${ }^{1, b}$ \\ ${ }^{1}$ Department of Physics Education, Faculty of Teacher Training and Education, \\ Universitas Sarjanawiyata Tamansiswa \\ Jalan Batikan UH.III/1043, Yogyakarta 55167, Indonesia

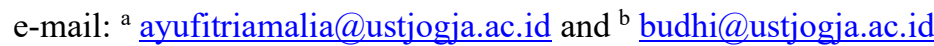 \\ * Corresponding Author
}

\begin{abstract}
The digital image processing is one way to manipulate one or more digital images. Image segmentation has an essential role in the field of image analysis. The aim of this study was to develop an application to perform digital image processing of neutron digital radiographic images, hoping to improve the image quality of the digital images produced. The quality of edge detection could be used for the introduction of neutron digital radiographic image patterns through artificial intelligence. Interaction of neutrons with the matter mainly by nuclear reaction, elastic, and inelastic scattering. A neutron can quickly enter into a nucleus of an atom and cause a reaction. It is because a neutron has no charge. Neutrons can be used for digital imaging due to high-resolution information from deep layers of the material. The attenuated neutron beam in neutron radiography are passing through the investigated object. The object in a uniform neutron beam is irradiated to obtain an image neutron. The technique used in segmenting the neutron radiography in this study was a digital technique using a camera with a charge-coupled device (CCD), which was deemed more efficient technique compared to the conventional one. Through this technique, images could be displayed directly on the monitor without going through the film washing process. Edge detection methods were implemented in the algorithm program. It was the first step to complement the image information where edges characterize object boundaries. It is useful for the process of segmenting and identifying objects in neutron digital radiography images. The edge detection methods used in this study were Sobel, Prewitt, Canny, and Laplacian of Gaussian. According to the results of the image that have been tested for edge detection, the best image was carried out by the Canny operator because the method is more explicit. The obtained edges were more connected than the other methods which are still broken. The Canny technique provided edge gradient orientation which resulted in a proper localization.
\end{abstract} Keywords: neutron radiography; digital image; edge detection

\section{Pola Citra Radiografi Digital Neutron Melalui Metode Deteksi Tepi}

\begin{abstract}
Abstrak
Memanipulasi satu atau beberapa citra dapat melalui pengolahan citra digital. Segmentasi citra yang merupakan proses pengolahan citra digital, memiliki peranan yang penting dalam analisis citra. Penelitian ini bertujuan untuk mengembangkan aplikasi pengolahan citra digital dari citra radiografi
\end{abstract}

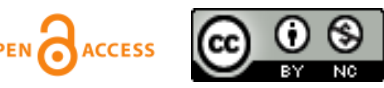


digital neutron yang dapat meningkatkan kualitas citra yang dihasilkan. Kualitas deteksi tepi dapat digunakan untuk pengenalan pola citra radiografi digital neutron melalui aplikasi kecerdasan buatan. Interaksi neutron dapat dimanfaatkan untuk pencitraan karena memiliki informasi resolusi tinggi pada lapisan material yang dalam. Berkas neutron yang teratenuasi pada radiografi neutron melewati objek yang diteliti. Objek dalam berkas neutron diiradiasi untuk mendapatkan citra. Teknik yang digunakan dalam radiografi neutron pada penelitian ini adalah teknik digital yang merupakan cara yang lebih efisien jika dibandingkan dengan teknik konvensional. Teknik digital menggunakan kamera Charge Coupled Device (CCD) sebagai pengganti film. Melalui teknik ini, citra dapat ditampilkan langsung pada monitor tanpa melalui proses pencucian film. Pengolahan citra radiografi digital neutron menggunakan perancangan algoritma yang dibuat secara sistematis, terstruktur, dan rapi sehingga hasil program dapat diupayakan berjalan sesuai dengan apa yang diharapkan. Metode deteksi tepi yang digunakan pada penelitian ini adalah Sobel, Prewitt, Canny, dan Laplacian of Gaussian. Hasil citra terbaik yang dianalisis melalui deteksi tepi citra menggunakan operator Canny. Tepi citra yang dihasilkan melalui operator Canny saling terhubung lebih jelas, sedangkan operator lainnya masih terputus-putus.

Kata Kunci: : radiografi neutron; citra digital; deteksi tepi

PACS: 28.20.Pr; 07.05.Pj; 87.59.bf

(C) 2020 Jurnal Penelitian Fisika dan Aplikasinya (JPFA). This work is licensed under CC BY-NC 4.0

\begin{tabular}{|c|c|}
\hline Article History: Received: October 7, 2019 & Approved with minor revision: January 23, 2020 \\
\hline Accepted: July 4, 2020 & Published: June 30, 2020 \\
\hline
\end{tabular}

How to cite: Amalia AF and Budi W. The Segmentation of Neutron Digital Radiography Image through the Edge Detection Method. Jurnal Penelitian Fisika dan Aplikasinya (JPFA). 2020; 10(1): 11-21. DOI: https://doi.org/10.26740/jpfa.v10n1.p11-21.

\section{INTRODUCTION}

$\mathrm{X}$-rays and Gamma rays are a beam of radiation created by the interaction of matter at the atomic level with the electron shell. They are mainly by three necessary processes: photoelectric effect, Compton scattering, and pair production. They intensively occur in the region of high electron-density because these are chiefly based on the interactions between photons and electrons [1]. Interaction of neutrons with the matter mainly by nuclear reaction, elastic, and inelastic scattering. A neutron can quickly enter into a nucleus of an atom and cause a reaction. It because a neutron has no charge. Incoherent scattering causes fast neutrons to interact. The probability decreases with the increasing atomic number [2].

During the radiation interaction either photoelectric effect or Compton, some of the photons interact with the matter and some Ayu Fitri Amalia and Widodo Budhi pass on the through called attenuation. While $\mathrm{x}$-ray attenuation depends on atomic number, neutron attenuated by only a few specific elements due to absorption and scattering [3]. $\mathrm{X}$-ray and Neutron radiography, both are nondestructive and non-invasive methods given insight into the function of devices and their decay processes [4].

Neutrons have high-resolution information from deep layers of the material which can be used for imaging [5]. The 25 $\mathrm{MeV}$ thermal neutron has zero charges. Therefore the penetration depth in most metals is higher compared to $120 \mathrm{keV}$ x-rays [6].

Through LI Hang's research, several hundred keV fast neutrons can penetrate some thermal neutron absorbers such as Cd. It was also feasible to investigate its use on some materials which are transparent to cold/thermal neutrons, such as Al [7]. Odin 
proposed that the high sensitivity of neutrons to hydrogen content was possible to track water diffusion through $3 \mathrm{~mm}$ thick samples without any special preparation in a relevant time range [8].

The attenuated neutron beam in neutron radiography are passing through the investigated object. The object in a uniform neutron beam is irradiated to obtain an image neutron. Prokhorets obtained the neutronradiography images using the transmission method. It shown the possibility of using the fast neutron for neutron-radiography imaging [9].

There are a number of method of neutron images producing including foils and x-ray film [10], computed radiography using image storage plates, real time scintillating screens with a CCD camera [11], neutron sensitive multi-channel plates [12], and other techniques.

The solution has been used for image recording through neutron scintillators coupled to Charge-Coupled Devices (CCD) video cameras and neutron imaging plates. The camera focused via a mirror on a scintillator screen [13]. A scintillator screen is used for converting the neutrons into optical light, while a mirror as additional components is used to prevent radiation damage of the camera [14].

Manipulation of one or more digital images can be involved by digital image processing. Digital image processing is the use of a computer algorithm to perform image processing on digital images [15]. Image segmentation has an essential role in the image analysis. It is used in pattern recognition and object detection, including the edge detection [16]. The image defined into meaningful parts or region by dividing spatial domain [15]. Edges is an image point where the gradient of image intensity function reaches its maximum local value [16].
Tremsin et al. [17], found that the artefacts of neutron radiography images should be treated properly. In addition, one should not confuse it for the real features of more complicated objects. It may not be easy to distinguish the edge effects from the various of attenuation coefficient in the sample. The application of micropore collimators can be a complimentary method in elimination of bright edges.

Hippmann proposed best suitable procedure for edge and line detection on large and small scales by using Qualitative Phase Contrast (QPC) imaging. It assesses low or nearly the same attenuation coefficient objects or composites resulting in a low absorption contrast. QPC imaging thus provides additional information such as enhanced contrast at edges and interfaces [18].

Some of the edges involve a step modification in intensity. Refraction or poor focus effect could lead to objects with boundaries by a gradual modification in intensity [19]. Edge detection has been developed for extracting edges from digital images by using techniques such as Roberts, Sobel, Prewitt, Kirsh, Robinson, MarrHildreth, LoG, and Canny edge detection [20].

Abubakar presented the study of Sobel, Canny, Robert, Prewitt, LoG (Laplacian of Gaussian) edge detection techniques for image segmentation. The experimental results obtained using the MATLAB version 7.12.0.635 (R2011a) software discussed highlight the performance of each method [21]. On another study, Krishnan et.al compared and analysed the performance of diverse edge detection techniques for recent digital image processing like Canny, Sobel, Prewitt, and LoG operator. The findings is that Canny provides better performance results under noise or complex images compared to other techniques [22]. In addition, the use of Canny technique could 
also exploit the information detection of brain tumour source through Magnetic Resonance Image (MRI) by Parthasarathy. It well defined tumour detection [23]. To add, Andrushia proposed various edge detection algorithms for concreate crack detection. They are Prewitt, Sobel, Gaussian, Roberts, Canny, and Laplacian. The edge detection methods produced reasonably good outputs [24].

The studies done by Abubakar, Krishnan, and Andrushia [21,22,24] are simple and use easy method that might possible to be used to enhance contrast at neutron digital radiography edges. So, it can be implemented to Tremsin and Hippmann's $[17,18]$. The present study, however, will use Canny, Sobel, Prewitt, Roberts, and LoG operator to extract the edges of neutron digital radiography images.

In this study, a significant improvement will be covered. The edge detection methods were applied to neutron digital radiography image due to low edge contrast as the problem of neutron radiography. The aim of this paper is to develop an application to perform digital image processing of neutron digital radiographic images, hoping to improve the image quality of the digital images produced. The quality of edge detection can be used for the introduction of neutron digital radiographic image patterns through artificial intelligence.

\section{METHOD}

The image used in this study was obtained by neutron digital radiography taken in BATAN Yogyakarta. The image is in grayscale bmp file format, because the inherent complexity of grayscale image is lower than colored image.

In this study, the detection of the shape of material is done by using optimized edge detection. It could not bother the color of image but to see actual shape of the material.
MATLAB is a very useful tool for image processing. Edge detection can use a special MATLAB function directly. The syntaxes are [25]:

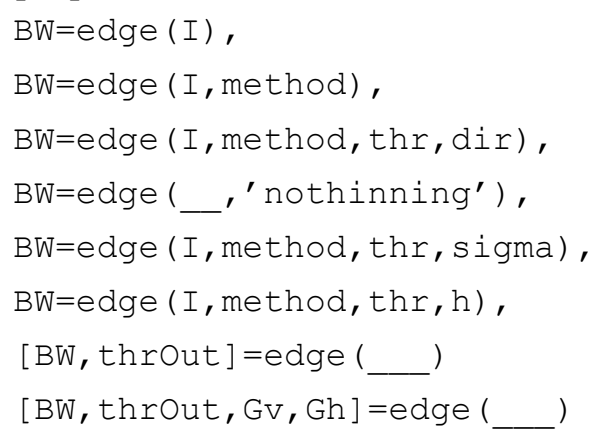

A binary image BW (edge map) is returned by $B W=e d g e(I)$. The specified edge detection algorithm used in this study were Roberts, Sobel, Prewitt, Canny, and Laplacian of Gaussian. By using those algorithms, $B W=$ edge ( $I$, method) detects edges in the image $I$. An edge detection algorithm may significantly reduce the amount of data to be processed due to less relevant information [26]. However, it still preserves the important structural properties of an image.

The edge detection should be tracked carefully by the edge detection algorithm. The false edges caused by noisy pixels also have to be eliminated by the edge detection algorithm. There are assumptions made in the edge tracing of images [27] namely (a) The gradient of edge pixels are stronger and greater than noise pixels, (b) The edge magnitude and orientation varies slowly along the edges

\section{Roberts Operator}

The Roberts cross gradient operator performs discrete differentiation. An input image has a spatial gradient that can be calculated absolutely by computing the total of squares of the different neighbouring pixels in the diagonal direction, as shown in Equation 1. It is the $3 \times 3$ pair convolution kernel. As shown in Equation 1, one is reasonable and the other rotated by $90^{\circ}$ [28]. 


$$
\left[\begin{array}{ccc}
1 & 0 & 0 \\
0 & -1 & 0 \\
0 & 0 & 0
\end{array}\right] \quad\left[\begin{array}{ccc}
0 & 1 & 0 \\
-1 & 0 & 0 \\
0 & 0 & 0
\end{array}\right]
$$

\section{Normal}

Rotated by $90^{\circ}$

Roberts edge detection was used as the first comparison in this study. The functions of Robert edge detection are as follows:

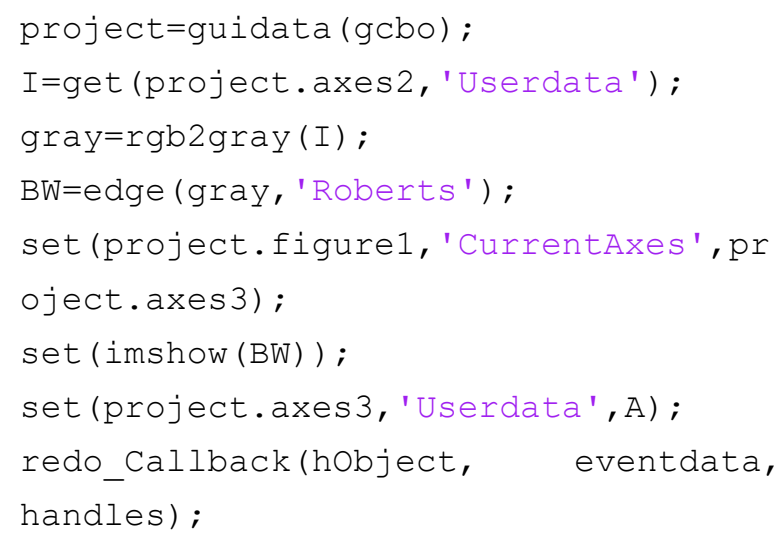

\section{Sobel Operator}

The Sobel operator is used to the opposite gradient in the horizontal and vertical direction of an image grid by introducing a minimal value of the filter. As shown in Equation 2, one kernel is standard and the other is rotated by $90^{0}$ [28].

$$
\left[\begin{array}{lll}
-1 & 0 & 1 \\
-2 & 0 & 2 \\
-1 & 0 & 1
\end{array}\right] \quad\left[\begin{array}{ccc}
-1 & -2 & 1 \\
0 & 0 & 0 \\
1 & 2 & 1
\end{array}\right]
$$

Normal

$$
\text { Rotated by } 90^{\circ}
$$

Detection of Edge Sobel was used as the second comparison in this study. The functions of Sobel edge detection are as follows:

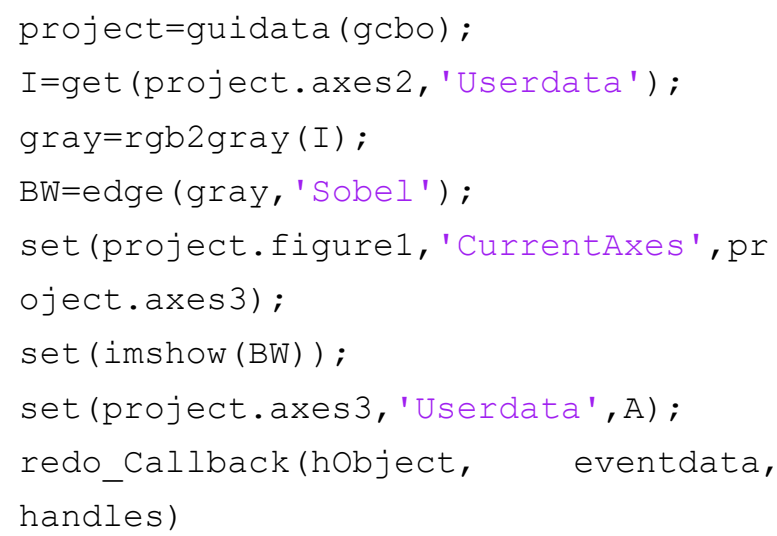

\section{Prewitt Operator}

Prewitt operator is similar to the Sobel, but Prewitt is slightly simpler. It tends to produce somewhat noisier results [20]. The masks are as shown in Equation 3.

$$
\left[\begin{array}{lll}
-1 & 0 & 1 \\
-1 & 0 & 1 \\
-1 & 0 & 1
\end{array}\right] \quad\left[\begin{array}{ccc}
-1 & -1 & -1 \\
0 & 0 & 0 \\
1 & 1 & 1
\end{array}\right]
$$

Normal Rotated by $90^{\circ}$

Prewitt edge detection was used as the third comparison in this study. The functions of Prewitt edge detection are as follows:

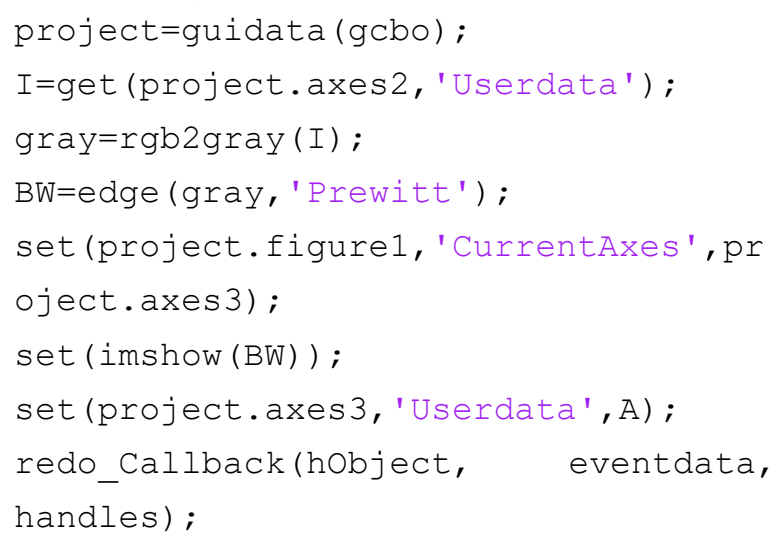

\section{Canny Operator}

Unlike Roberts and Sobel, the Canny operator is not easily affected by noise. It is one of the standard techniques in the industry field. It would be superior if the Canny worked well [20]. Detection of Canny uses two convolutions masks. They are the horizontal and vertical directions, as shown in Equation 4.

The Canny's algorithm requires the image to be filtered where the Sobel operator is applied onto it [29]. The blur edges and the unwanted edges is removed as the output of Sobel operator.

$$
\begin{gathered}
{\left[\begin{array}{ccc}
-1 & -1 & -1 \\
0 & 0 & 0 \\
1 & 1 & 1
\end{array}\right]} \\
\text { Normal } \\
\text { Rotated by } 90^{0}
\end{gathered}
$$

Canny edge detection was used as the fourth comparison in this study. The functions of Canny edge detection are as follows. 


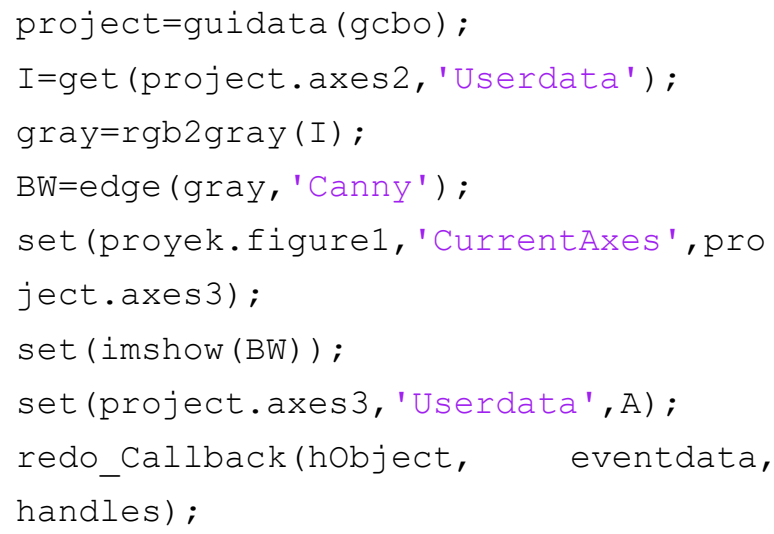

\section{Laplacian of Gaussian Operator}

The Laplacian of Gaussian operator is a second-order derivative technique obtained by considering the difference of differences, called central differences. It has two effects. Its first effect is to smoothen the image, and the second is to compute the Laplacian, which yields a double-edge image. The digital implementation of the Laplacian function is usually made through the mask, as shown in Equation 5.

$\left[\begin{array}{ccc}0 & -1 & 0 \\ -1 & 4 & -1 \\ 0 & -1 & 0\end{array}\right] \quad\left[\begin{array}{ccc}-1 & -1 & -1 \\ -1 & 8 & -1 \\ -1 & -1 & -1\end{array}\right]$

Normal

Rotated by $90^{\circ}$

The Laplacian of Gaussian (LoG) combines Gaussian filtering and the Laplacian for edge detection. The LoG mainly uses two methods which are mathematically similar. In the first method, it convolves the image with Gaussian smoothing filter and compute it with the Laplacian result. This pre-processing step reduces the high frequency noise components prior to the differentiation step. In the second one, it shall convolve the image with the linear LoG filter [30].

Since both the Gaussian and the Laplacian are usually much smaller than the image, these methods usually require far fewer arithmetic operations. The 2D LoG equation centered on zero and with the Gaussian standard deviation $\sigma$ has the form [31]:

$$
\operatorname{LoG}(x, y)=-\frac{1}{\pi \sigma^{4}}\left[1-\left(\frac{x^{2}+y^{2}}{2 \sigma^{2}}\right)\right] e^{\frac{x^{2}+y^{2}}{2 \sigma^{2}}}
$$

The LoG operator become as simple as Laplacian operator shown in Equation 5.

Detection of LoG was used as the fifth comparison in this study. The functions of LoG edge detection are as follows.

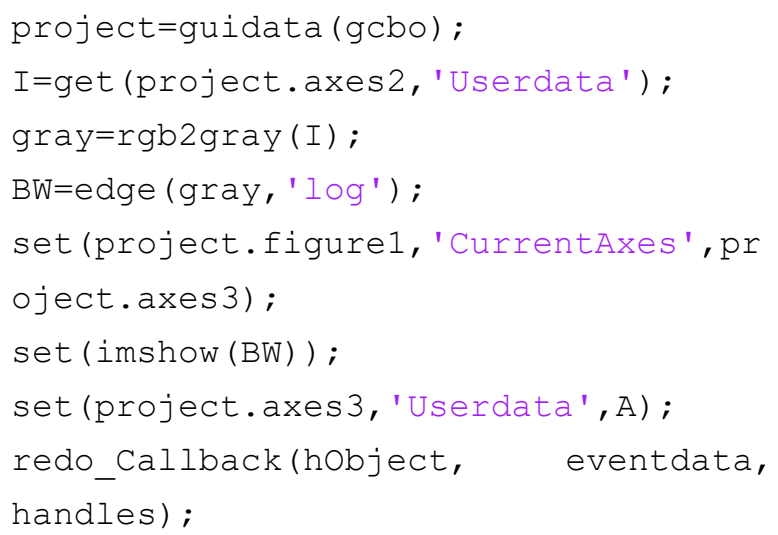

\section{RESULTS AND DISCUSSION}

Neutron radiography is a nondestructive testing. As a result of interaction with matter, neutron penetrates the obejcts. It can transmit the material layers with certain thickness which depend on the specific attenuation properties of material [32].

Kartini is nuclear reactor located in BATAN, Yogayakarta regency. It is a TRIGA (Training Research and Isotope production General Atomic) categorized as inherent safety reactor. TRIGA Mark II is research reactor designed and manufactured by General Atomic [33]. It is utilized in various field such as Neutron Activation Analysis (NAA), radiography and tomography, education, and training [34].

The experiment was done using 300 digital neutron digital radiography images of a metal that had been normalized. The image was stored in the format of a bitmap (*.bmp) measuring $720 \times 480$ pixels. GUI MATLAB is used to implement the edge detection techniques, and the image of neutron digital radiography is tested, as shown in Figure 1. The problems and solutions are uttered in recognizable mathematical details [35]. 
Jurnal Penelitian Fisika dan Aplikasinya (JPFA), 2020; 10(1): 11-21

Two axes are used in this GUI. The first GUI is database axes which store some images and the input image taken from open block. The second one shows the image after edge detection processing. The actual image and the processed images by using various kinds of edge detection techniques are shown in Figure 2.

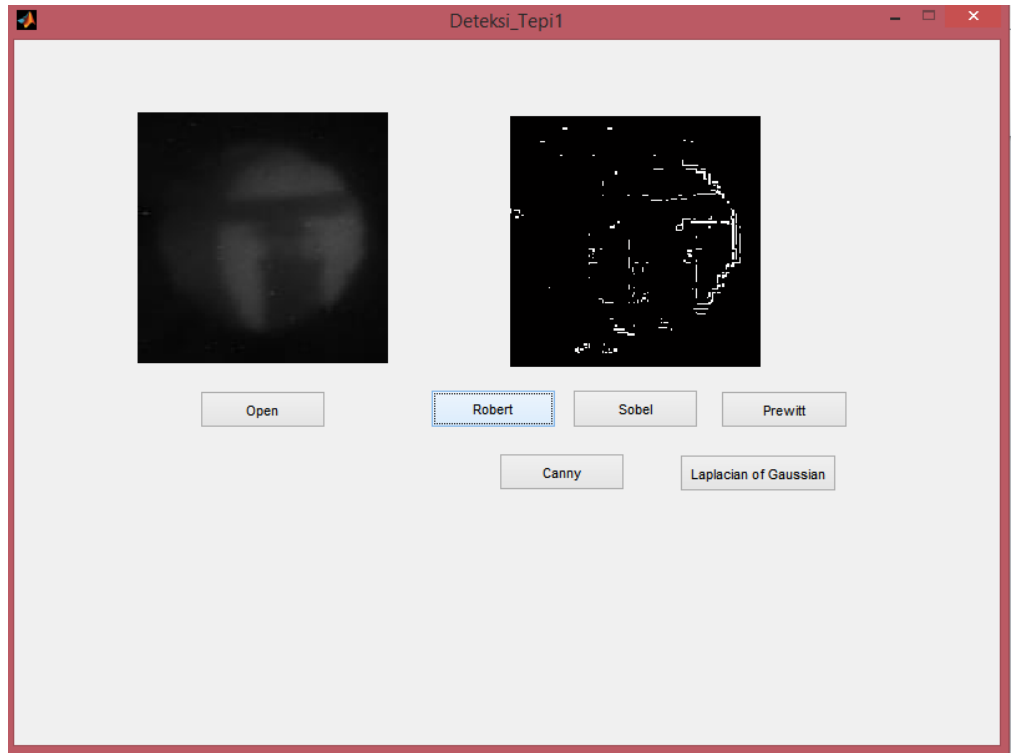

Figure 1. Implementation of Edge Detection Algorithms Program

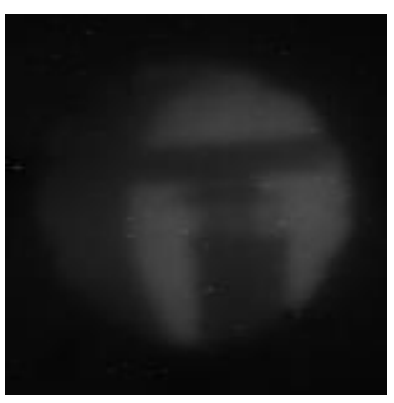

Original (Grayscale image)

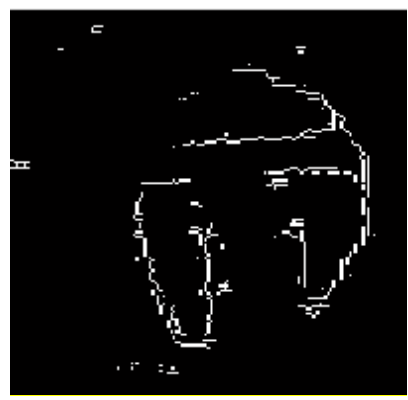

Prewitt

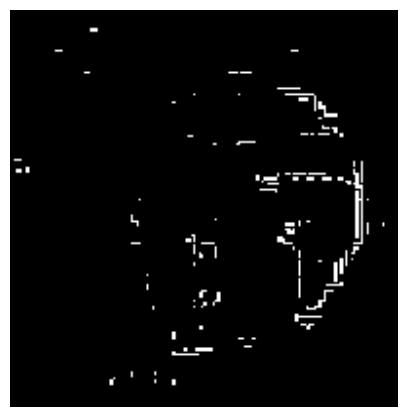

Robert

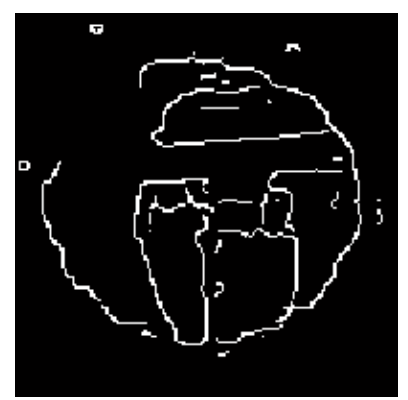

Canny

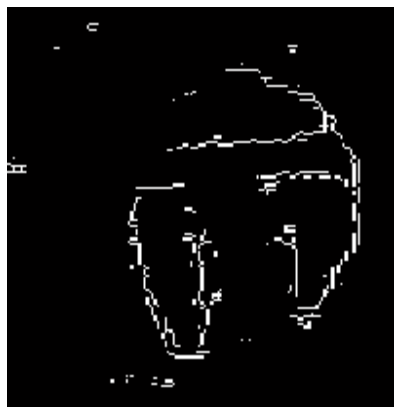

Sobel

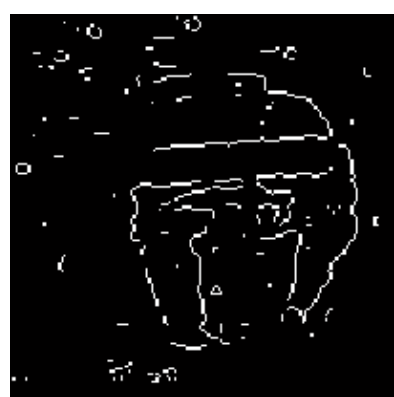

LoG

Figure 2. Original Image Compared to Various Kinds of Edge Detection Techniques 
From the experiment, the Robert operator is rapid to compute, while the Sobel is slower than the Roberts operator. The images processed with Robert technique, however, is close to the ones produced by Sobel one. As seen, the edge quality of the pixels are degraded due to the jerky effect on the edges. In contrast, although the Sobel operator had a larger convolution kernel which smooths the input image to a greater extent, when it comes to locating the intricate edges, a Sobel operator is not accurate [37]. Katiyar and Arun through their studies supposed that the Sobel is weaker than Prewitt.

The resulting image processed using Robert and Prewitt detect the various features and stadium. However, they fail when the features are smaller and the range of threshold is very low [38].

Compared to the other techniques, seen from Figure 2 that Canny operator detected the edges of the object image in a more clearly manner without any discontinuity. Satbir Kaur and Ishpreet Singh have studied a comparison between edge detection techniques, proving that Canny technique can extract the features in the image without disturbing its features [39].

The Robert, Sobel, Prewitt, and LoG operator are less sensitive to noise. Compare to Canny operator, LoG has great extent in removing noise after twofold differentiation. Unfortunately, the LoG operator is unable to find edge orientation while the Canny provides edge gradient orientation, which results in proper localization. Li Bin and Mehdi Samiei Yeganeh proposed that the LoG operator is rarely used for direct edge detection because it often produces the edge of second pixels full [40].

Edge detection can be brought to medical image enhancement research area to produce a more efficient medical radiographic images. The Canny operator is advisable and recommended for a detailed framework of human anatomy. MRI and X-Ray images often consist of the important and meaningful edges, i.e. bones.

\section{CONCLUSION}

In this study, the various edge detection method for image segmentation was applied to neutron digital radiography image using MATLAB software. The algorithm works well on the neutron digital radiography image. From the experiments, Canny and LoG produce almost similar edges, while Robert is much closer to Sobel and Prewitt. Compared to the other techniques, Canny is deemed better producing optimal performance.

\section{ACKNOWLEDGMENT}

The author gratefully acknowledges Lembaga Penelitian, Pengembangan dan Pengabdian Kepada Masyarakat Univeristas Sarjanawiyata Tamansiswa (LP3M UST) for funding the study under internal grant "Dosen Pemula" through SK No. 20/UST/LP3M/PUSLIT/K/PDP/V/2018.

\section{REFERENCES}

[1] Hohara S and Nohtomi A. Neutron Radiography. Osaka: Atomic Energy Research Institute, Kinki University; 1895.

[2] Schillinger B, Calzada E, and Lorenz K. Modern Neutron Imaging: Dynamic and Phase Contrast Imaging with Neutrons. Solid State Phenomena. 2006; 112: 61-72. DOI: http://dx.doi.org/10.4028/www.scientific.net/ SSP.112.61.

[3] Eldin MTA. Neutron Radiography. Alexandria: Alexandria University; 2011.

[4] Banhart J, Borbély A, Dzieciol K, GarciaMoreno F, Manke I, Kardjilov N, KaysserPyzalla AR, Strobl M, and Treimer W. X-Ray and Neutron Imaging - Complementary Techniques for Materials Science and Engineering. International Journal of Materials Research. 2010; 101(9): 1069- 
Jurnal Penelitian Fisika dan Aplikasinya (JPFA), 2020; 10(1): 11-21

1079. DOI:

https://doi.org/10.3139/146.110382.

[5] Szilágyi V, Kis Z, and Szentmiklósi L. Neutron Imaging For Archaeometry. Archeometriai Mühely. 2016; 3(13): 157-172. Available from:

http://www.ace.hu/am/2016 3/AM-2016-3SZV.pdf.

[6] Kardjilov N, Manke I, Hilger A, Strobl M, and Banhart J. Neutron Imaging in Neutron Imaging. Materials Today. 2011; 14(6): 248256. DOI:

http://dx.doi.org/10.1016/S13697021(11)70139-0.

[7] Hang L, Yu-Bin Z, Yuan-Rong L, Zhi-Yu G, and Gou-You T. Preliminary Study on Neutron Radiography with Several Hundred KeV Fast. Chinese Physics Letters. 2012; 29(11): 118701. DOI:

http://dx.doi.org/10.1088/0256307X/29/11/118701.

[8] Odin GP, Rouchon V, Ott F, Malikova N, Levitz P, and Michot LJ. Neutron Imaging Investigation of Fossil Woods: NonDestructive Characterization of Microstructure and Detection of in Situ Changes as Occurring in Museum Cabinets. Fossil Record. 2017; 20(1): 95-103. DOI: http://dx.doi.org/10.5194/fr-20-95-2017.

[9] Prokhorets SI and Khazhmurodov MA. Object Imaging Using Neutron-Radiography Methods. Problems Of Atomic Science And Technology. 2016; N5(105): 73-76. Available from:

https://vant.kipt.kharkov.ua/ARTICLE/VANT 2016 5/article 2016 5 73.pdf.

[10] Domanus JC. Practical Neutron Radiography. 1st Edition. Netherlands: Springer; 1992.

[11] Lehmann EH, Frei G, Ku G, and Boillat P. The Micro-Setup for Neutron Imaging: A Major Step Forward to Improve the Spatial Resolution. Nuclear Instruments and Methods in Physics Research Section A: Accelerators, Spectrometers, Detectors and
Associated Equipment. 2007; 576(2-3): 389 396. DOI:

https://doi.org/10.1016/j.nima.2007.03.017.

[12] Tremsin AS, McPhate JB, Vallerga JV, Siegmund OHW, Feller WB, Lehmann E, Butler LG, and Dawson M. High-Resolution Neutron Microtomography with Noiseless Neutron Counting Detector. Nuclear Instruments and Methods in Physics Research Section A: Accelerators, Spectrometers, Detectors and Associated Equipment. 2011; 652(1): 400-403. DOI: https://doi.org/10.1016/j.nima.2010.08.009.

[13] Kaestner A, Lehmann E, and Stampanoni M. Imaging and Image Processing in Porous Media Research. Advances in Water Resources. 2008; 31(9): 1174-1187. DOI: https://doi.org/10.1016/j.advwatres.2008.01. $\underline{022}$.

[14] B̈orries S. Neutron Imaging of Metal Hydride Systems. Dissertation. Hamburg: University of Hamburg; 2017.

[15] Rashmi, Kumar M, and Saxena R. Algorithm and Technique on Various Edge Detection : a Survey. Signal \& Image Processing: An International Journal (SIPIJ). 2013; 4(3): 65-75. DOI:

http://dx.doi.org/10.5121/sipij.2013.4306.

[16] Goswami B and Misra SK. Analysis of Various Edge Detection Methods for X-Ray Images. 2016 International Conference on Electrical, Electronics, and Optimization Techniques (ICEEOT). Chennai. 2016: 2694-2699. DOI:

http://dx.doi.org/10.1109/ICEEOT.2016.775 $\underline{5185}$.

[17] Tremsin AS, Lehmann EH, Kardjilov N, Strobl M, Manke I, McPhate JB, Vallerga JV, Siegmund OHW, and Feller WB. Refraction Contrast Imaging and Edge Effects in Neutron Radiography. Journal of Instrumentation. 2012; 7(2): C02047. DOI: https://dx.doi.org/10.1088/1748$\underline{0221 / 7 / 02 / \mathrm{c} 02047 .}$. 
Jurnal Penelitian Fisika dan Aplikasinya (JPFA), 2020; 10(1): 11-21

[18] Hippmann S, Lorenz K, Bogenberger C, and Hoffmann H. Edge Detection within Qualitative Phase Contrast Neutron Radiographies of Castings. Nuclear Instruments \& Methods in Physics Research Section A-accelerators Spectrometers Detectors and Associated Equipmen.. 2009; 605(1-2): 30-32. DOI:

http://dx.doi.org/10.1016/j.nima.2009.01.12 2.

[19] Hussain SK and Rafi RM. Comparisions of Robert, Pewit, Sobel Operators Based Edge Detection Methods. International Journal of Latest Engineering Research and Applications (IJLERA). 2017; 2(10): 51-56. Available from:

http://www.ijlera.com/papers/v2i10/20.201710520.pdf.

[20] Muthukrishnan R and Radha M. Edge Detection Techniques for Image Segmentation. International Journal of Computer Science \& Information Technology (IJCSIT). 2011; 3(6): 259-267. Available from:

https://www.researchgate.net/publication/27 4872300 Edge_Detection_Techniques_For Image Segmentation.

[21] Abubakar FM. Study of Image Segmentation by Using Edge Detection Techniques. International Journal of Engineering Research \& Technology (IJERT). 2012; 1(9): 1-5. Available from:

https://www.ijert.org/study-of-imagesegmentation-by-using-edge-detectiontechniques.

[22] Krishnan KB, Ranga SP, and Guptha N. A Survey on Different Edge Detection Techniques for Image Segmentation. Indian Journal of Science and Technology. 2017; 10(4): 1-8. DOI:

http://dx.doi.org/10.17485/ijst/2017/v10i4/1 $\underline{08963}$.

[23] Parthasarathy G, Ramanathan L, Anitha K, and Justindhas Y. Predicting Source and Age of Brain Tumor Using Canny Edge Detection
Algorithm and Threshold Technique. Asian Pacific Journal of Cancer Prevention. 2019; 20(5): 1409-1414. DOI:

http://dx.doi.org/10.31557/APJCP.2019.20.5 .1409 .

[24] Andrushia AD, Anand N, and Godwin IA. Analysis of Edge Detection Algorithms For Concrete Crack Detection. International Journal of Mechanical Engineering and Technology (IJMET). 2018; 9(11): 689-695. Available from:

http://www.iaeme.com/ijmet/IJMET_Paper. asp?sno=13998.

[25] Hagara $M$ and Kubinec P. About Edge Detection in Digital Images. Radioengineering. 2018; 27(4): 919-929. DOI:

https://dx.doi.org/10.13164/re.2018.0919.

[26] Gill R, Kaur N, and Singla AK. A Comparative Analysis of Edge Detection Operators: Application for Text Detection. International Journal of Computer Science and Technology (IJCST). 2012; 3(4): 530533. Available from:

http://ijcst.com/vol34/3/rana.pdf.

[27] Kumar SN, Fred AL, H AK, and Varghese S. Medical Image Edge Detection Using Gauss Gradient Operator. Journal of Pharmaceutical Science and Research (JPSR). 2017; 9(5): 695-704. Available from:

https://www.jpsr.pharmainfo.in/Documents/ Volumes/vol9Issue05/jpsr09051731.pdf.

[28] Shubhangi DC, Chinchansoor RS, and Hiremath P. Edge Detection of Femur Bones in X-Ray Images - A Comparative Study of Edge Detectors. International Journal of Computer Applications. 2012; 42(2): 13-16. Available from:

https://www.ijcaonline.org/archives/volume 42/number2/5664-7696.

[29] Susmitha A, Mishra A, Sharma D, Wadhwa $\mathrm{P}$, and Dash L. Implementation of Canny's Edge Detection Technique for Real World Images. International Journal of 
Jurnal Penelitian Fisika dan Aplikasinya (JPFA), 2020; 10(1): 11-21

Engineering Trends and Technology (IJETT).

2017; 48(4): 176-181. DOI:

http://dx.doi.org/10.14445/22315381/IJETTV48P232.

[30] Shrivakshan GT and Chandrasekar C. A Comparison of Various Edge Detection Techniques Used in Image Processing. IJCSI International Journal of Computer Science Issues. 2012; 9(5): 269-276. Available from: https://www.ijcsi.org/articles/A-survey-ofedge-detection-techniques-used-in-imageprocessing-with-a-case-study.php.

[31] Maini R and Aggarwal H. Study and Comparison of Various Image Edge Detection Techniques. International Journal of Image Processing (IJIP). 2009; 3(1): 1-11. Available from:

https://www.cscjournals.org/library/manuscr iptinfo.php?mc=IJIP-15.

[32] Amalia AF, Budhi W, Prabowo UN, and Suparta GB. The Image Quality Analysis of Neutron Digital Radiography through the Variation of Multiple Image Capturing. AIP Conference Proceedings. 2018; 2014: 020140. DOI:

https://dx.doi.org/10.1063/1.5054544.

[33] Cammi A, Zanetti M, Chiesa D, Clemenza M, Pozzi S, Previtali E, Sisti M, Magrotti G, Prata M, and Salvini A. Characterization of the TRIGA Mark II Reactor Full-Power Steady State. Nuclear Engineering and Design. 2016; 300: 308-321. DOI: http://dx.doi.org/10.1016/j.nucengdes.2016. $\underline{01.026}$.

[34] Hakim SUE, Abimanyu A, and Sutanto. Simulator Design of Kartini Reactor Based on LABVIEW. Jurnal Forum Nuklir (JFN). 2018; 12(1): 29-41. Available from: http://jurnal.batan.go.id/index.php/jfn/article /view/3646.
[35] Pawar PH and Patil RP. Image Edge Detection Techniques Using MATLAB Simulink. International Journal of Engineering Research \& Technology (IJERT). 2014; 3(6): 2149-2153. Available from: https://www.ijert.org/image-edgedetection-techniques-using-matlab-simulink.

[36] Leavline EJ and Singh DAAG. On Teaching Digital Image Processing with MATLAB. American Journal of Signal Processing. 2014; 4(1): 7-15. Available from: http://article.sapub.org/10.5923.j.ajsp.20140 401.02.html.

[37] Mohammad EJ, JawadKadhim M, Hamad WI, Helyel SY, Alrsaak AAA, Al-Kazraji FKS, and HadeeAbud AS. Study Sobel Edge Detection Effect on the ImageEdges Using MATLAB. International Journal of Innovative Research in Science, Engineering and Technology. 2014; 3(3): 10408-10415. Available from:

https://www.ijirset.com/upload/2014/march/ 68 Study.pdf.

[38] Katiyar SK and Arun PV. Comparative Analysis of Common Edge Detection Techniques in Context of Object Extraction. IEEE Transactions on Geoscience and Remote Sensing. 2012; 50(11): 68-79. Available from:

https://arxiv.org/abs/1405.6132.

[39] Kaur S and Singh I. Comparison between Edge Detection Techniques. International Journal of Computer Applications. 2016; 145(15): 15-18. DOI: http://dx.doi.org/10.5120/ijca2016910867.

[40] Bin L and Samiei M. Comparison for Image Edge Detection Algorithms. IOSR Journal of Computer Engineering (IOSRJCE). 2012; 2(6): 1-4. DOI: http://dx.doi.org/10.9790/0661-0260104. 